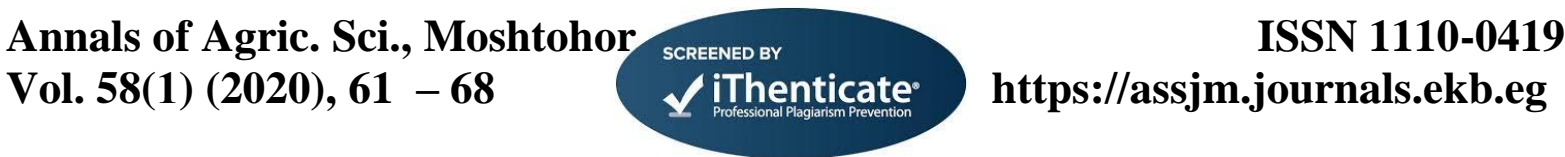

\title{
Prediction of N, K and Mg on Leaves of Four Citrus Rootstocks Seedlings Using Hyper Spectral Data
}

${ }^{1}$ Selim A.I., ${ }^{2}$ Sharaf M.M. and ${ }^{2}$ EL-Gioushy S.F.

${ }^{1}$ Agriculture Application Department, National Authority for Remote Sensing and Space science (NARSS), Egypt.

${ }^{2}$ Department of Horticulture, Faculty of Agriculture, Benha University, Egypt.

Corresponding author: adelselem335@gmail.com

\begin{abstract}
Sufficient application of nutrients is one of the most important factors in the development of seedlings from quality citrus root stocks. Some of the key guides for preparing citrus fertilizer programs is by tracking the nutrient content of plants directly. This includes, however, an examination of a large number of leaf samples using costly and time-chemical techniques. It has been shown over the last 10 years that it is possible to quantitatively estimate such nutrient elements in citrus leaves using the spectral reflectance values obtained using hyperspectral spectroscopy. This technique is quick, non-destructive, cost-effective and eco- friendly. Therefore, estimating nitrogen, potassium, and magnesium in seedling leaves of citrus rootstocks by this approach would be useful in determining the seedlings ' mineral status. In this research,168 leaf samples from four citrus rootstocks seedlings (Volkamer lemon, Sour orange, Trifoliate orange and Balady Lime) were used to conduct three vegetation indices; normalized difference vegetation index (NDVI), normalized difference nitrogen index (NDNI) and modified chlorophyll absorption ratio index (MCARI) and subsequent nutrient estimates for $\mathrm{N}, \mathrm{K}$, and $\mathrm{Mg}$ concentration. Simple regression models and chemical analysis were used to produce the best model of estimation to predict the values of the three components. A high correlation coefficient (R2) was verified in the estimate of $\mathrm{N}(\mathrm{R} 2=0.982)$ with the lowest root mean square error $(\mathrm{RMSE}=0.0472)$ and $\mathrm{k}(\mathrm{R} 2=0.983)$ with the lowest root mean square error $(\mathrm{RMSE}=0.0491)$ and the lowest root mean square error (RMSE=0.0062) was also verified.
\end{abstract}

Keywords: Nitrogen, Nutritional status, Potassium, Magnesium ,Citrus, Seedling, Rootstocks , Hyperspectral, VIS, NDNI,NDNI ,MCARI.

\section{Introduction}

Citrus is Egypt's most important type of fruit. It is the largest horticultural industry in the last few years and the harvested area has increased rapidly from year to year and has reached 530415 fed. The citrus fruiting acreage is fed at 440706. Produced an annual report of 4402180 tons (depending on the Ministry of Agriculture and Land Recovery 2014).

Citrus trees are generally propagated on rootstocks rather than as seedlings or cuttings because rootstocks offer some benefits for a citrus tree irrespective of its use as a commercial, ornamental or doory crop.Citrus rootstocks therefore play a vital role in the quality and quantity of citrus plants ' production and survival.Volkamer lemona relatively new rootstock in the citrus industry .trees on Volkamer lemon are generally similar in behavior but superior to those on rough lemon. Volkamer lemon is suitable for use in a wide range of soils under most conditions Young trees ' vigor and productivity on this stock make it particulate. Sour orange is a distinctive, readily recognized citrus species with numerous variants, most of which as root stocks have no value. Trees budded on sour orange are growing slightly slower than those on rough lemon, but they produce a tree of moderate vegetative vigor and size. The yield of fruit varies greatly with the type of soil .Trifoliate orange is a rootstock of global significance that has been used on a limited basis for many years. BaladyLime (benzhair) Because of its resistance to thirst or drought conditions, its cultivation succeeds in new lands, particularly in sandy soil, and its fruits are characterized by a high acidity ratio of 6-9 percent (in addition to being rich in vitamin $\mathrm{C}$, and farmers have been very keen on cultivating this variety in recent years because of the abundance of the plant.Like other fruit trees, the production of citrus root stocks requires the right combination of nitrogen, potassium, phosphorus and trace elements for robust growth such as manganese, boron, copper and magnesium.Leaf analysis offered a guide for fertilizer applications based on the sufficiency range (SR), a system focused on separate indices of nutrients, including only one nutrient in each index (Walsh, 1973; Jones et al., 1991).

A shortage of any mineral nutrients, particularly nitrogen, potassium and phosphorus, can lead to different stress-induced responses such as limited shoots and growth of roots, early defoliation of older leaves and reduced biomass yield as described in many studies (Trumble, J. T et al., 1993).

Precise estimation of plant nutrient needs based on leaf optical properties such as fluorescence, reflectance and transmittance is also gaining wide attention in agriculture. The leaf nutrient content was analyzed using spectral reflectance data to determine appropriate wavelengths to predict the contents of the most essential leaf nutrients: nitrogen, phosphorus, potassium, calcium, magnesium, boron, copper and zinc(Santosoet al., 2019).Monitoring the impact of plant nutrition on fruit production may require a 
variety of complex laboratory chemical analyzes, with certain studies that need to be performed over several years to draw the correct conclusions. This also leads to a large number of samples to be analyzed; this is very time-consuming work, leading to high economic costs and, of course, Have a negative environmental effect on the development of hazardous chemicals during the research techniques. Therefore, it would be highly beneficial to establish a rapid, environmentally friendly and cheaper method of analysis (Galvez-Sola et al., 2015).

Hyper spectral remote sensing and vegetation indeces ( VIS) Has the potential to be a useful tool in the rapid analysis of various samples collected from long-term experiments. Therefore, the aim of this study was to explore the predictive ability of the Hyper spectral remote sensing and vegetation indeces (VIS) in the evaluation of several elements in citrus root stocks seedlings leaves of different species.

\section{Materials and Methods}

This study was conducted during the two successive growing seasons (2017/2018 and 2018/2019) on some citrus rootstocks Seedlings at the Faculty of Agriculture, Banha, Qaliubiya Governorate - Egypt It is located in Egypt between $31^{\circ} 13^{\prime} 30$ "and $30^{\circ} 30^{\prime \prime E}$ longitudes and $30^{\circ} 21$ '30" and 30²1'30"Nlatitudes: Figure(1).

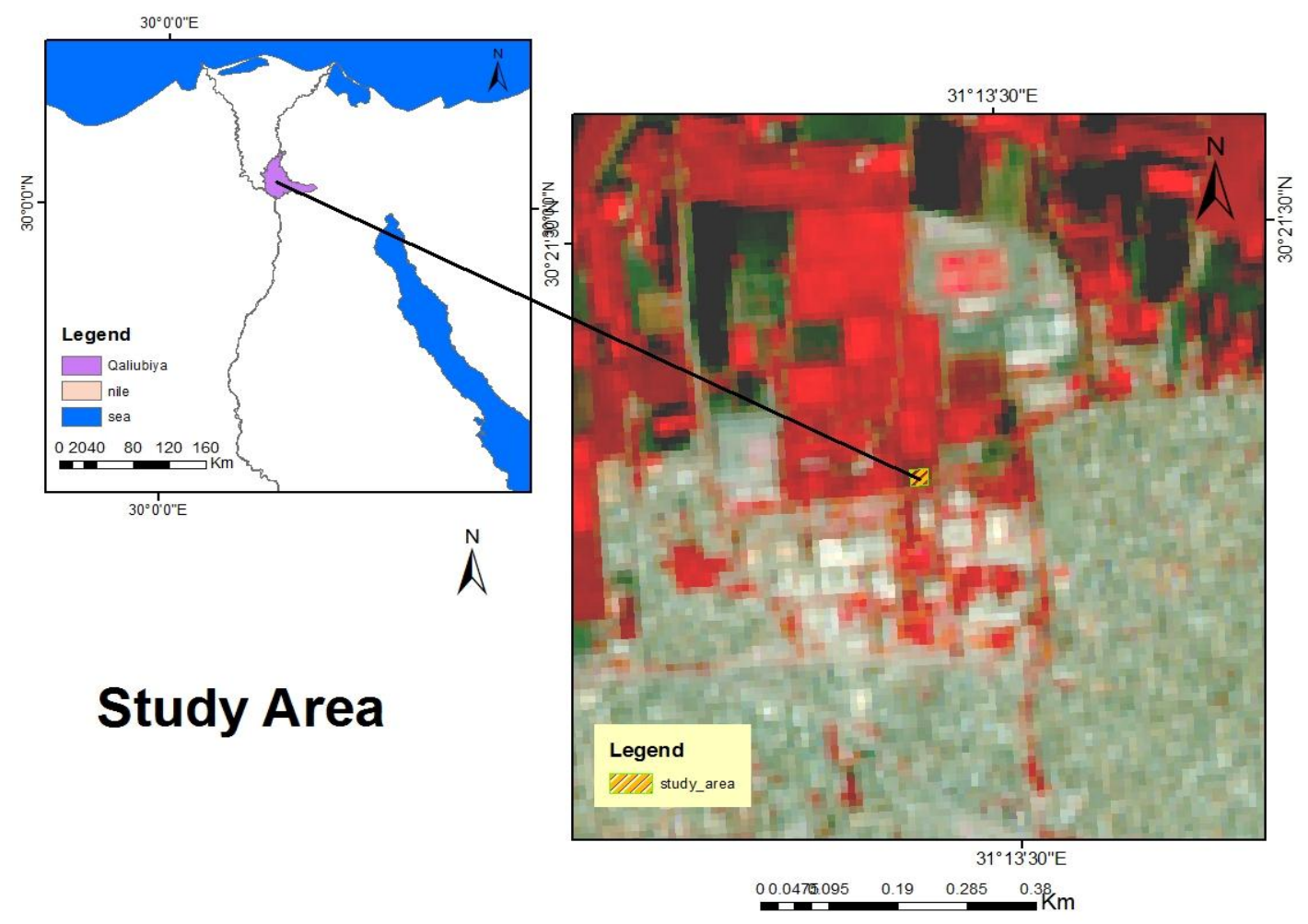

Fig. (1): Study area

\section{Experimental Design}

A randomized experiment with three pot replicates was conducted to monitor the effect of different rates of fertilizer applications on four Seedlings citrus rootstocks.

\section{Steps to conduct the experiment:}

1. Recycling rootstockes seedlings at the age of six months in pots measuring $15 \mathrm{~cm}$ at the beginning of Mayfor each season

2. Ensure the success of seedlings after recycling in pots

3. Seven fertilizer transactions are performed on each rootstocke as follows:

- Control

- 1 gm net weight of nitrogen element

- 2 gm net weight of nitrogen element

- 2 gm net weight of potassium element
- $4 \mathrm{gm}$ net weight of potassium element

- $0.25 \mathrm{gm}$ net weight of magnesium element

- 0.5 gm net weight of magnesium element

Citrus root stockesseedlinges Leaves Samples

total of 168 leaf samples from different species were used in this research,including 42 of each species (Volkamer lemon, Sour orange ,Trifoliate orange,BaladyLime)

\section{TradionalanalysisofLeaf mineral content:}

Samples of leaves were carefully removed from the treated plants and cleaned with cotton clothes.

Tap water several times accompanied by distilled water. Samples were dried for constant weight and soil in a blender at $70 \mathrm{oC}$ in an oven. Then, $0.5 \mathrm{~g}$. Using the $\mathrm{H} 2 \mathrm{SO} 4$ and $\mathrm{H} 2 \mathrm{O} 2$ as defined by Cottenie (1980) were digested of dried samples. The mineral content of the leaves was calculated by the extracted samples: N, P, 
$\mathrm{K}$ and $\mathrm{Mg}$ as macro-elements and $\mathrm{Fe}, \mathrm{Zn}$ and $\mathrm{Mn}$ as micro-elements as follows:

Nitrogen (N) percent: Nitrogen was calculated by Plummer (1971) using the revised micro-kjeldahl process.

Potassium (K) percentage: Potassium was measured against the Piper (1950) flame-photometer model (Model-JENWAY-pfp7 Flame Photometer).

Magnesium (Mg) percentage: Magnesium was determined by titration with the Richards (1954)versenate solution in plant digest.

\section{Field hyper spectral measurements:}

Analytical field spectro radiometer (ASD Field Spec) was used to calculate the reflection of the various Seedlings data collected through the touch prob instrument. Measurements are performed in a complete optical spectral array (Visible-Near Infrared-Short Wave Infrared) from $350 \mathrm{~nm}$ to 2500 $\mathrm{nm}$ with output data of $1 \mathrm{~nm}$ of interval. At the spectral range $(350-1050 \mathrm{~nm})$, the sampling interval is $1.4 \mathrm{~nm}$, while at the spectral range $(1000-2500 \mathrm{~nm})$ it is $2 \mathrm{~nm}$.
The unit conducts data interpolation automatically and provides the final data output with $(1 \mathrm{~nm})$ interval for the full range of spectrum $(350-2500 \mathrm{~nm})$.

\section{Spectral data analysis:}

ViewSpec program can convert ASCII text files to spectral data from binary file. Afile can be converted at a time. Instead, several files can be merged into a single text file, a helpful function when inputting information into other statistical software such as Microsoft Excel. All measurements of Spectral reflection have been converted to open in Microsoft Excel.

Vegetation indices (VIs):

The indices of vegetation (VIs) have been generated. VIs is a mathematical transformation that can maximize the difference in vegetation coverage in spectral reflectance. In this analysis, three vegetation indices were tested: normalized deference vegetation index (NDVI) equation (1), modified chlorophyll absorption ratio index (MCARI) equation (2), nitrogen deference vegetation index (NDNI) equation (3). are shown in Table (a).

Table (a): Showed all equations of all vegetation indices

\begin{tabular}{|c|c|c|}
\hline VIs & Equation & Ref \\
\hline NDVI & $\frac{(\mathrm{R} 800-\mathrm{R} 670)}{(\mathrm{R} 800+\mathrm{R} 670)}$ & $\begin{array}{l}\text { Eq1: Rouse et } \\
\quad \text { al,1974 }\end{array}$ \\
\hline MCARI & {$[(\mathrm{R} 700-\mathrm{R} 670)-0.2(\mathrm{R} 700-\mathrm{R} 550)] *\left(\frac{\mathrm{R} 700}{670}\right)$} & $\begin{array}{c}\text { Eq2: } \\
\text { Daughtry et } \\
\text { al,2000 }\end{array}$ \\
\hline NDNI & $\log (1510 \mathrm{~nm})-\log (1680 \mathrm{~nm}) / \log (1510 \mathrm{~nm})+\log (1680 \mathrm{~nm})$ & $\begin{array}{c}\text { Eq3: } \\
\text { Bao et al, } \\
2013\end{array}$ \\
\hline
\end{tabular}

\section{Statistics generated models:}

Vegetation indices and laboratory leaves minerals for each rootstock Were imported to the Statistical Package of the Social Sciences (SPSS) version 23 statistical software for descriptive statistical analysis .We made relationships between the dependent (leaf mineral content) and independent (vegetation indices) variables involved in the simple regression models analysis.

$\mathrm{Y}=\mathrm{a}+\mathrm{b} * \mathrm{x}$ Eq (4) (Simple linear regression model) Where, $\mathrm{Y}$ is the actual leaves element content, $\mathrm{X}$ are vegetation indices. $a$ is

Intercept.$b$ is the regression coefficients. The relation is linear between predict and predictors. For linear relationships were applied the basic linear regression models. Linearity between content of leaves components and indices of vegetation was achieved using SPSS 23. To measure the model's goodness-of-fitness the square of the correlation coefficient (R2) was determined. This takes values between 0 (points are totally random) and 1 (all points lie exactly on the line of regression). (R2) defines the proportion of the total variability of the leaf item content $(\mathrm{Y})$ that is clarified by the linear relationship of $\mathrm{Y}$ over the entire vegetation index and provides an indication of the fit-of-model.

\section{Results and Discussion}

As explained in table (1), the three vegetation indices that were statistically examined as estimators for Nitrogen concentration for Volkamer lemon leaves showed high accuracy. The highest correlation coefficient $\left(r^{2}=0.954\right)$ with the lowest root mean square error (RMSE=0.109) was found with NDNI followed by NDVI when MCARI index model showed the lowest correlation coefficient and highest RMSE. 
Table 1. Simple regression models and validation for Volkamer lemon leaves Nitrogen concentration prediction.

\begin{tabular}{cccccc}
\hline $\begin{array}{c}\text { Input } \\
\text { factor }\end{array}$ & $\begin{array}{c}\text { Intercept } \\
\text { (a) }\end{array}$ & $\begin{array}{c}\text { Slope } \\
\text { Coefficient }(\mathbf{b})\end{array}$ & Generated model & $\begin{array}{c}\text { Correlation } \\
\text { coefficient } \\
\left(\mathbf{R}^{2}\right)\end{array}$ & RMSE \\
\hline NDVI & -5.523 & 8.789 & $\mathrm{Y}=-5.523+8.789 *$ NDVI & .902 & 0.1718 \\
NDNI & -3.653 & 24.148 & $\mathrm{Y}=-3.653+24.148^{*}$ & .954 & 0.1092 \\
& & & NDNI & & .795 \\
MCARI & .895 & 1.409 & $\mathrm{Y}=.895+1.409^{*}$ MCARI & 0.2347 \\
\hline
\end{tabular}

Table 2. Simple regression models and validation for Volkamer lemon leaves potassium concentration prediction.

\begin{tabular}{cccccc}
\hline $\begin{array}{c}\text { Input } \\
\text { factor }\end{array}$ & $\begin{array}{c}\text { Intercept } \\
\text { (a) }\end{array}$ & $\begin{array}{c}\text { Slope } \\
\text { Coefficient (b) }\end{array}$ & Generated model & $\begin{array}{c}\text { Correlation } \\
\text { coefficient }\left(\mathbf{R}^{2}\right)\end{array}$ & RMSE \\
\hline NDVI & -5.685 & 8.678 & $\mathrm{Y}=-5.685+8.678^{*}$ NDVI & .723 & 0.3372 \\
NDNI & -4.272 & 25.769 & $\mathrm{Y}=-4.272+25.769^{*}$ & .893 & 0.2368 \\
& & & NDNI & & 0.1256 \\
\hline
\end{tabular}

As explained in table (2), the three vegetation indices that were statistically examined as estimators for potassium concentration for Volkamer lemon leaves showed high accuracy. The highest correlation coefficient $\left(r^{2}=0.965\right)$ with the lowest root mean square error $(\mathrm{RMSE}=0.1256)$ was found with MCARI followed by NDNI when NDVI index model showed the lowest correlation coefficient and highest RMSE.

Table 3. Simple regression models and validation for Volkamer lemon leaves Magnesium concentration prediction.

\begin{tabular}{cccccc}
\hline $\begin{array}{c}\text { Input } \\
\text { factor }\end{array}$ & $\begin{array}{c}\text { Intercept } \\
\text { (a) }\end{array}$ & $\begin{array}{c}\text { Slope } \\
\text { Coefficient }\end{array}$ (b) & Generated model & $\begin{array}{c}\text { Correlation } \\
\text { coefficient }\left(\mathbf{R}^{2}\right)\end{array}$ & RMSE \\
\hline NDVI & -.067 & .359 & $\mathrm{Y}=-.067+.359^{*} \mathrm{NDVI}$ & .928 & 0.0062 \\
NDNI & 0.018 & .951 & $\mathrm{Y}=0.018+.951^{*} \mathrm{NDNI}$ & .912 & 0.0073 \\
MCARI & .196 & .056 & $\mathrm{Y}=.196+.056^{*} \mathrm{MCARI}$ & .784 & 0.0105 \\
\hline
\end{tabular}

As explained in table (3), the three vegetation indices that were statistically examined as estimators for Magnesium concentration for Volkamer lemon leaves showed high accuracy. The highest correlation coefficient $\left(r^{2}=0.928\right)$ with the lowest root mean square error (RMSE $=0.0062)$ was found with NDVI followed by NDNI when MCARI index model showed the lowest correlation coefficient and highest RMSE.

Table 4. Simple regression models and validation for Sour orange leaves Nitrogen concentration prediction.

\begin{tabular}{cccccc}
\hline $\begin{array}{c}\text { Input } \\
\text { factor }\end{array}$ & $\begin{array}{c}\text { Intercept } \\
\text { (a) }\end{array}$ & $\begin{array}{c}\text { Slope } \\
\text { Coefficient }(\mathbf{b})\end{array}$ & Generated model & $\begin{array}{c}\text { Correlation } \\
\text { coefficient }\left(\mathbf{R}^{2}\right)\end{array}$ & RMSE \\
\hline NDVI & -7.122 & 10.649 & $\mathrm{Y}=-7.122+10.649^{*}$ & .945 & 0.0872 \\
NDNI & -2.326 & 18.459 & $\mathrm{~N}=-2.326+18.459^{*}$ & .982 & 0.0472 \\
& & & NDNI & & \\
MCARI & 1.149 & .920 & $\mathrm{Y}=1.149+.920^{*}$ MCARI & .559 & 0.2723 \\
\hline
\end{tabular}

As explained in table (4), the three vegetation indices that were statistically examined as estimators for Nitrogen concentration for Sour orange leaves showed high accuracy. The highest correlation coefficient $\left(r^{2}=0.982\right)$ with the lowest root mean square error (RMSE=0.0472) was found with NDNI followed by NDVI when MCARI index model showed the lowest correlation coefficient and highest RMSE.

Table 5. Simple regression models and validation for Sour orange leaves potassium concentration prediction.

\begin{tabular}{|c|c|c|c|c|c|}
\hline $\begin{array}{l}\text { Input } \\
\text { factor }\end{array}$ & $\begin{array}{c}\text { Intercept } \\
\text { (a) } \\
\end{array}$ & $\begin{array}{c}\text { Slope } \\
\text { Coefficient (b) } \\
\end{array}$ & Generated model & $\begin{array}{c}\text { Correlation } \\
\text { coefficient }\left(\mathbf{R}^{2}\right)\end{array}$ & RMSE \\
\hline NDVI & -6.906 & 9.933 & $\mathrm{Y}=-6.906+9.933^{*} \mathrm{NDVI}$ & .836 & 0.1440 \\
\hline NDNI & -2.360 & 16.894 & $Y=-2.360+16.894 *$ NDNI & .836 & 0.1787 \\
\hline
\end{tabular}




\begin{tabular}{llllll}
\hline MCARI & .619 & 1.140 & $\mathrm{Y}=.619+1.140 *$ MCARI & .874 & 0.1677 \\
\hline
\end{tabular}

As explained in table (5), the three vegetation indices that were statistically examined as estimators for potassium concentration for Sour orange leaves showed high accuracy. The highest correlation coefficient $\left(r^{2}=0.874\right)$ with the lowest root mean square error $(\mathrm{RMSE}=0.1677)$ was found with MCARI followed by NDVI when MCARI index model showed the lowest correlation coefficient and highest RMSE.

Table 6. Simple regression models and validation for Sour orange leaves Magnesium concentration prediction.

\begin{tabular}{cccccc}
\hline $\begin{array}{c}\text { Input } \\
\text { factor }\end{array}$ & $\begin{array}{c}\text { Intercept } \\
(\mathbf{a})\end{array}$ & $\begin{array}{c}\text { Slope } \\
\text { Coefficient }(\mathbf{b})\end{array}$ & Generated model & $\begin{array}{c}\text { Correlation } \\
\text { coefficient }\left(\mathbf{R}^{2}\right)\end{array}$ & RMSE \\
\hline NDVI & -.206 & .534 & $\mathrm{Y}=-.206+.534 * \mathrm{NDVI}$ & .889 & 0.0057 \\
NDNI & -.044 & .881 & $\mathrm{Y}=-.044+.881^{*} \mathrm{NDNI}$ & .838 & 0.0878 \\
MCARI & .201 & .057 & $\mathrm{Y}=.201+.057 * \mathrm{MCARI}$ & .795 & 0.0110 \\
\hline
\end{tabular}

As explained in table (6), the three vegetation indices that were statistically examined as estimators for Magnesium concentration for Sour orange leaves showed high accuracy. The highest correlation coefficient $\left(r^{2}=0.889\right)$ with the lowest root mean square error (RMSE=0.0057) was found with NDVI followed by NDVI when MCARI index model showed the lowest correlation coefficient and highest RMSE.

Table 7. Simple regression models and validation for Trifoliate orange leaves Nitrogen concentration prediction.

\begin{tabular}{cccccc}
\hline $\begin{array}{c}\text { Input } \\
\text { factor }\end{array}$ & $\begin{array}{c}\text { Intercept } \\
(\mathbf{a})\end{array}$ & $\begin{array}{c}\text { Slope } \\
\text { coefficient }(\mathbf{b})\end{array}$ & Generated model & $\begin{array}{c}\text { Correlation } \\
\text { coefficient }\left(\mathbf{R}^{2}\right)\end{array}$ & RMSE \\
\hline NDVI & -2.045 & 4.642 & $\mathrm{Y}=-2.045+4.642 *$ NDVI & .885 & 0.0766 \\
NDNI & -.112 & 7.416 & $\mathrm{Y}=-.112+7.416 *$ NDNI & .864 & 0.0767 \\
MCARI & .829 & 1.803 & $\mathrm{Y}=.829+1.803^{*}$ MCARI & .975 & 0.0498 \\
\hline
\end{tabular}

As explained in table (7), the three vegetation indices that were statistically examined as estimators for Nitrogen concentration for Trifoliate orange leaves showed high accuracy. The highest correlation coefficient $\left(\mathrm{r}^{2}=0.975\right)$ with the lowest root mean square error $(\mathrm{RMSE}=0.0498)$ was found with MCARI followed by NDVI when NDNI index model showed the lowest correlation coefficient and highest RMSE.

Table 8. Simple regression models and validation for Trifoliate orange leaves potassium concentration prediction.

\begin{tabular}{cccccc}
\hline $\begin{array}{c}\text { Input } \\
\text { factor }\end{array}$ & $\begin{array}{c}\text { Intercept } \\
\text { (a) }\end{array}$ & $\begin{array}{c}\text { Slope } \\
\text { coefficient }(\mathbf{b})\end{array}$ & Generated model & $\begin{array}{c}\text { Correlation } \\
\text { coefficient( }\end{array}$ & RMSE \\
\hline NDVI & -4.757 & 8.448 & $\mathrm{Y}=-4.757+8.448^{*}$ NDVI & .892 & 0.1518 \\
NDNI & -1.280 & 13.684 & $\mathrm{Y}=-1.280+13.684^{*}$ NDNI & .895 & 0.1476 \\
MCARI & .471 & 3.283 & $\mathrm{Y}=.471+3.283 *$ MCARI & .983 & 0.0491 \\
\hline
\end{tabular}

As explained in table (8), the three vegetation indices that were statistically examined as estimators for potassium concentration for Trifoliate orange leaves showed high accuracy. The highest correlation coefficient $\left(r^{2}=0.983\right)$ with the lowest root mean square error $(\mathrm{RMSE}=0.0491)$ was found with MCARI followed by NDNI when NDVI index model showed the lowest correlation coefficient and highest RMSE.

Table 9. Simple regression models and validation for Trifoliate orange leaves Magnesium concentration prediction.

\begin{tabular}{cccccc}
\hline $\begin{array}{c}\text { Input } \\
\text { factor }\end{array}$ & $\begin{array}{c}\text { Intercept } \\
\text { (a) }\end{array}$ & $\begin{array}{c}\text { Slope } \\
\text { Coefficient }(\mathbf{b})\end{array}$ & Generated model & $\begin{array}{c}\text { Correlation } \\
\text { coefficient }\left(\mathbf{R}^{2}\right)\end{array}$ & RMSE \\
\hline NDVI & -1.120 & 1.857 & $\mathrm{Y}=-1.120+1.857 *$ NDVI & .547 & 0.0561 \\
NDNI & -.342 & 2.942 & $\mathrm{Y}=-.342+2.942 *$ NDNI & .525 & 0.0541 \\
MCARI & -.007 & .824 & $\mathrm{Y}=-.007+.824 *$ MCARI & .785 & 0.0560 \\
\hline
\end{tabular}

As explained in table (9), the three vegetation indices that were statistically examined as estimators for Magnesium concentration for Trifoliate orange leaves showed high accuracy. The highest correlation coefficient $\left(r^{2}=0.785\right)$ with the lowest root mean square error (RMSE=0.056) was found with MCARI followed by NDVI when NDNI index model showed the lowest correlation coefficient and highest RMSE. 
Table 10. Simple regression models and validation for Balady Lime leaves Nitrogen concentration prediction.

\begin{tabular}{cccccc}
\hline $\begin{array}{c}\text { Input } \\
\text { factor }\end{array}$ & $\begin{array}{c}\text { Intercept } \\
\text { (a) }\end{array}$ & $\begin{array}{c}\text { Slope } \\
\text { coefficient } \\
\text { (b) }\end{array}$ & Generated model & $\begin{array}{c}\text { Correlation } \\
\text { coefficient } \\
\left(\mathbf{R}^{2}\right)\end{array}$ & RMSE \\
\hline NDVI & -2.400 & 4.773 & $\mathrm{Y}=-2.400+4.773 *$ NDVI & .744 & 0.1256 \\
NDNI & .132 & 5.953 & $\mathrm{Y}=.132+5.953 *$ NDNI & .845 & 0.0991 \\
MCARI & 1.041 & .883 & $\mathrm{Y}=1.041+.883 *$ MCARI & .968 & 0.0385 \\
\hline
\end{tabular}

As explained in table (10), the three vegetation indices that were statistically examined as estimators for Nitrogen concentration for Balady Lime leaves showed high accuracy. The highest correlation coefficient $\left(\mathrm{r}^{2}=0.968\right)$ with the lowest root mean square error $(\mathrm{RMSE}=0.0385)$ was found with MCARI followed by NDNI when NDVI index model showed the lowest correlation coefficient and highest RMSE.

Table 11. Simple regression models and validation for Balady Lime leaves potassium concentration prediction.

\begin{tabular}{cccccc}
\hline $\begin{array}{c}\text { Input } \\
\text { factor }\end{array}$ & $\begin{array}{c}\text { Intercept } \\
\text { (a) }\end{array}$ & $\begin{array}{c}\text { Slope } \\
\text { Coefficient }(\mathbf{b})\end{array}$ & Generated model & $\begin{array}{c}\text { Correlation } \\
\text { coefficient }\left(\mathbf{R}^{2}\right)\end{array}$ & RMSE \\
\hline NDVI & -5.505 & 8.823 & $\mathrm{Y}=-5.505+8.823 *$ NDVI & .671 & 0.2883 \\
NDNI & -.999 & 11.734 & $\mathrm{Y}=-.999+11.734 * \mathrm{NDNI}$ & .867 & 0.1847 \\
MCARI & 0.838 & 1.665 & $\mathrm{Y}=0.838+1.665^{*} \mathrm{MCARI}$ & .908 & 0.1403 \\
\hline
\end{tabular}

As explained in table (11), the three vegetation indices that were statistically examined as estimators for potassium concentration for BaladyLime leaves showed high accuracy. The highest correlation coefficient $\left(\mathrm{r}^{2}=0.908\right)$ with the lowest root mean square error $(\mathrm{RMSE}=0.1403)$ was found with MCARI followed by NDNI when NDVI index model showed the lowest correlation coefficient and highest RMSE.

Table 12. Simple regression models and validation for BaladyL ime leaves Magnesium concentration prediction.

\begin{tabular}{cccccc}
\hline $\begin{array}{c}\text { Input } \\
\text { factor }\end{array}$ & $\begin{array}{c}\text { Intercept } \\
\text { (a) }\end{array}$ & $\begin{array}{c}\text { Slope } \\
\text { Coefficient }(\mathrm{b})\end{array}$ & Generated model & $\begin{array}{c}\text { Correlation } \\
\text { coefficient }\left(\mathrm{R}^{2}\right)\end{array}$ & RMSE \\
\hline NDVI & -.820 & 1.311 & $\mathrm{Y}=-.820+1.311 *$ NDVI & .773 & 0.0338 \\
NDNI & -.109 & 1.569 & $\mathrm{Y}=-.109+1.569 *$ NDNI & .809 & 0.0288 \\
MCARI & .133 & .230 & $\mathrm{Y}=.133+.230 *$ MCARI & .904 & 0.0162 \\
\hline
\end{tabular}

As explained in table (12), the three vegetation indices that were statistically examined as estimators for Magnesium concentration for BaladyLime leaves showed high accuracy. The highest correlation coefficient $\left(r^{2}=0.904\right)$ with the lowest root mean square error $(\mathrm{RMSE}=0.0162)$ was found with MCARI followed by NDNI when NDVI index model showed the lowest correlation coefficient and highest RMSE.

The main objective of the current study is to observe the correlation between spectral characteristics of different citrus leaves for different root stocks and to generate applicable empirical models to estimate microelements using spectral measurements. This proposed approach could be used effectively instead of laboratory analytical tests or at least it could be used to reduce them.

A total of one hundred sixty samples (168) during two growing seasons were used to examine the correlation and to produce the empirical models. Generally, the three examined spectral factors in form of vegetation indices (VIs) showed high correlation with the concentration of the three macro elements when observed with the different root stocks. As shown from all tables that the correlation coefficients for the generated linear regression models between spectral factors and microelements concentration were relatively high ranged from $(0.525)$ to $(0.983)$ when the root mean square error (RMSE) ranged from $(0.0057)$ to $(0.3372)$. These results clearly approved that spectral reflectance characteristics are highly correlated with the concentration of macro elements and the spectral factors could be used to predict the concentration of macro elements in plant leaves using the generated statistical models.

\section{Discussion:}

The main advantages of using this technique are that -after calibration of the element of interest- it is possible to obtain a precise quantitative approximation of the element within one minute, with the use of chemical reagents and thus without generating pollutants. This method is also less costly than conventional chemical-based approaches, and doesnot involves laborious sample preparation prior to analysis.(Cohen et al,. 2010) estimated potato leaf $\mathrm{N}$ levels using spectral data and simulated VEN $\mu \mathrm{S}$ satellite bands suggesting $\mathrm{N}$ levels of fertilizer application, achieving an overall $\mathrm{R} 2$ value of 0.95 , an overall accuracy of 80.5 percent and a 74 percent kappa coefficient (almost) value..( Albayraket al., 
2008) assessed reflectance levels in a sainfoin pasture for determining nitrogen $(\mathrm{N})$, phosphorus $(\mathrm{P})$, potassium $(\mathrm{K})$, acid detergent fibre, and neutral detergent fiber content, and found a strong association between plant nutrient content and canopy reflectance with determination coefficient (R2) values in the range of 0.68-0.93range.(Menesatti et al,.2010) calculated plant nutritional status using spectrophotometric analysis of orange leaves, visible to near infrared (NIR) and obtained high R2 values of $0.91,0.43,0.99,0.95,0.94,0.92,0.93$ and 0.89 for $\mathrm{N}$, $\mathrm{P}, \mathrm{K}$, calcium $(\mathrm{Ca})$, magnesium $(\mathrm{Mg})$, iron $(\mathrm{Fe})$, manganese $(\mathrm{Mn})$, and zinc $(\mathrm{Zn})$, respectively.

\section{Conclusion:}

The current study proposed an approach to use hyper spectral remote sensing data in order to estimate plant nutrition status and to predict the concentration of macro elements in plant leaves. To achieve the main objective of the current study, field spectral measurements were carried out for one hundred sixty eight (168) samples of citrus leaves during two growing seasons. The study could successfully generate empirical statistical models based on linear regression between spectral factors represented by three vegetation indices and the concentration of three elements. The generated models could be used to replace or to reduce the laboratory analytical tests that are currently used world-wide. Generally, the results are quite sufficient however, advanced work should be carried out to examine the proposed models over more agricultural seasons and more samples, more rootstocks as well.

\section{References:}

Albayrak, S. (2008). Use of reflectance measurements for the detection of $\mathrm{N}, \mathrm{P}, \mathrm{K}, \mathrm{ADF}$ and NDF contents in sainfoin pasture. Sensors, 8(11), 7275-7286.

Bao, Y., Xu, K.;Min, J., and Xu, J. (2013). Estimating wheat shoot nitrogen content at vegetative stage from in situ hyperspectral measurements. Crop science, 53(5), 2063-2071.

Cohen, Y; Alchanatis, V.;Zusman, Y.;Dar, Z.; Bonfil, D. J.; Karnieli, A.; and Brikman, R. (2010). Leaf nitrogen estimation in potato based on spectral data and on simulated bands of the $\mathrm{VEN} \mu \mathrm{S}$ satellite. Precision agriculture, 11(5), 520-537.
Cottenie, A. (1980). Soil and plant testing as a basis of fertilizer recommendations (No. 38/2).

Daughtry, C. S. T.; Walthall, C. L.;Kim, M. S.; De Colstoun, E. B.; and McMurtrey Iii, J. E. (2000). Estimating corn leaf chlorophyll concentration from leaf and canopy reflectance. Remote sensing of Environment, 74(2), 229-239.

enesatti, P.; Antonucci, F.; Pallottino, F.; Roccuzzo, G., Allegra, M.; Stagno, F., and Intrigliolo, F. (2010). Estimation of plant nutritional status by Vis-NIR spectrophotometric analysis on orange leaves [Citrus sinensis (L) OsbeckcvTarocco]. Biosystems engineering, 105(4), 448-454.

Galvez-Sola, L.; García-Sánchez, F. .; Pérez-Pérez, J. G.; Gimeno, V., Navarro, J. M. .; Moral, R. and Nieves, M. (2015). Rapid estimation of nutritional elements on citrus leaves by near infrared reflectance spectroscopy. Frontiers in plant science, 6, 571 .

Jones,J.;Wolf,B.;andMills,H.(1991). PlantAnalysisHandbook. Athens,GA: MicroMacroPublishing.

Plummer, J. T. (1971). Life style patterns and commercial bank credit card usage. Journal of Marketing, 35(2), 35-41.

Richards, L. A. (1954). Diagnosis and improvement of saline and alkali soils (Vol. 78, No. 2, p. 154). LWW.

Rouse, J. W.; Haas, R. H.; Schell, J. A., and Deering, D. W. (1974). Monitoring vegetation systems in the Great Plains with ERTS. NASA special publication, 351, 309

Santoso, H.; Tani, H; Wang, X., and Segah, H. (2019). Predicting oil palm leaf nutrient contents in kalimantan, I ndonesia by measuring reflectance with a spectroradiometer. International journal of remote sensing, 40(19), 7581-7602.

Trumble, J. T; Kolodny- Hirsch, D. M., and Ting, I. P. (1993). Plant compensation for arthropod herbivory. Annual review of entomology, 38(1), 93-119.

Walsh,L.M.(1973).SoilandAppliedNitrogen.Soiand AppliedPhosphorus.SoilandAppliedPotassium.So ilandAppliedBoron.SoilandAppliedCalcium.Soila ndAppliedMagnesium.UniversityofWisconsinExt ensionBulletinA2519toA2524.

Madison,WI:UniversityWisconsinExtension. 
التنبؤ بالغناصر الغذائية (النيتروجين, البوتاسيوم والماغنسيوم) فى اولق اريعة أصول للموالح بأستخدام البيانات فائقة الاطياف.

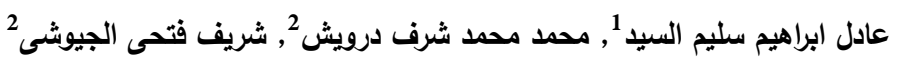

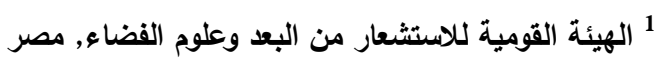

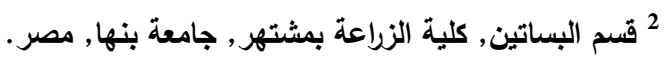

ان التطبيق الجيد للتغذية السليمة هو أحد اهم العناصر للحصول على شتلات اصول موالح جيدة وبالتالى الحصول على اشجار موالح سليمة

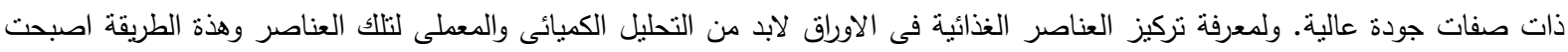
مكلفة وتستهلك الوقت لذلك فى السنوات الاخيرة اتجه بعض الباحثين لتقدير نلك العناصر الغذائية بأستخدام الطرق الحديثة منها استخدام تقنيات

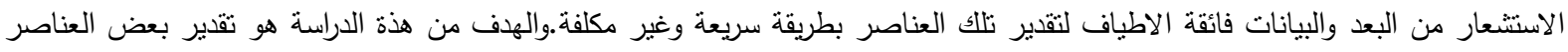
الغذائية فى اوراق شتلات بعض اصول الموالح بأستخدام الادلة الخضرية المستتجة من البيانات فائقة الاطياف. وقد تم تسجيل الدراسة فى مشتل

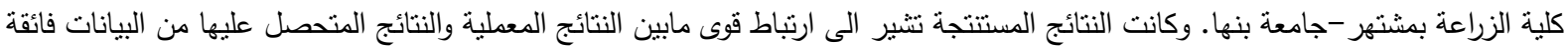

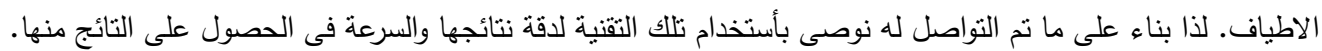

